\title{
The Relationship Between the Practice of Suluk with Psychological Well Being Among the Saliks at Tarekat Naqsyabandiyah and Non-Saliks
}

\author{
Raras Sutatminingsih \\ Clinical Psychology Departement, North Sumatera University, Indonesia \\ rarasiskandar20030yahoo.com
}

\begin{abstract}
This research examines the relationship between the practice of suluk and psychological well-being among the saliks practicing suluk at Tarekat Naqsyabandiyah and among those who are non-saliks. This research uses method of quantitative method. The subjects of the study are the Muslim population in the city of Medan. They consist of those who have practiced suluk and those who have not practiced suluk at Tarekat Naqsyabandiyah, and the are between 40 and 59 years old. The collection of quantitative data uses the psychological well-being questionnaire. The sample consists of 200 saliks and 200 nonsaliks. Analysis of quantitative data was performed using the simple and multiple linear regression techniques. The findings from the quantitative analysis showed that the practice of suluk is positively related with psychological well-being and all its aspects.
\end{abstract}

Keywords - suluk, saliks, transcendental, religious, psychological well-being.

\section{INTRODUCTION}

This study anticipates that regardless of whether people practice suluk or not, their activities will have an influence on their psychological well-being. Suluk also called seclusion, that is located in a quiet place, in order to pray fervently and perfect. One who performs suluk called Salik. The salik isolated in mosques, prayer house, or any place that corresponds, as exemplified by the Prophet Muhammad. Period did suluk maybe ten days, twenty days, thirty days, forty days, or on the direction of the supervising teacher. Those who wish to carry out suluk have to do so under the leadership of a supreme knowledge, held by Sheikh Murshid [1].

Furthermore, suluk is endeavor to Allah, solely to seek his relaxation. The essence of suluk is the attempt, endeavor earnestly to clean the physical and spiritual, by repenting and emptying ourselves rather than vices (vice outer and inner) and fill it with admirable qualities, obedient and unseen. Everyone who acts suluk believes he will be clean and repentance will be accepted by Allah SWT, so it will be taqarrub, which is close to God [2]

Ryff and Keyes [3] defined psychological wellbeing in a comprehensive way in relation to whether the individual has a goal in life, whether the individual can realize the potential he or she has, his or her relationship with other people, and whether the individual is responsible towards his or her own life.

Past studies have shown that the teachings of the tarekat can prevent people from vice, increase piety and piousness in performing religious duties, and make people become committed and sincere in helping others. Furthermore, it can also increase piousness and earnestness in fulfilling the social obligations as demanded by the religious teachings [4]. Other studies have also shown that Yoga Hatha and meditation can reduce anxiety, significantly enhance mental health and factors of life quality, reduce negative mood, depression, fatigue, bewilderment, heartbeat, improve physical health, reduce pain, improve immunity, improve emotional life, help spiritual development, and significantly improve antibody effect of influenza vaccine. [5]

Maltby, Lewis, and Day [6] found that there is a positive relationship between people who pray and their subjective well-being. The relationship between ritual praying and deep devotion in meditative prayers, frequency of praying, and experience in praying are all correlated with subjective well-being. Those who perform prayers, feel the presence of Allah, and remember Him, recite their dua (prayers) accordingly, will feel deeply secure, and will feel a deep experience with Allah. They reported that they can feel a better subjective well-being. Scully, Kremer, Meade, Graham, and 
Dudgeon [7] found that religion has a large and significant influence on health and psychological well-being, especially the influence from religious organizations.

Looking at the results of past studies, therefore this research studies the variables of suluk practice and psychological well-being. Additionally, this study also found that research on the practice of Suluk from the psychological perspective is much lacking. Hence, this research needs to be conducted.

This study aims to test the following research hypotheses that there is a positive relationship between suluk practice and psychological well-being among the salik (or salikeen) and non-salik (or nonsalikeen). Therefore, this research aims to examine the relationship between suluk practice and psychological well-being.

Saliks (or salikeen) are subjects of the study who have practised suluk with TarekatNaqsyabandiyah at least once. Meanwhile, non-saliks are subjects of the study who have not practised suluk with any tarekat group. However, the saliks under study will involve only the followers of the 10-day suluk programme organised at Tarekat Naqsyabandiyah in Medan, Indonesia. Saliks and non-saliks selected to be informant in this study were in their 40s (40-49 years old) and 50s (50-59 years old) and consisted of males and females.

\section{METHOD}

\section{A. Participants}

Participants for the study consisted of 200 saliks from the Tarekat Naqsyabandiyah as the subjects because all the saliks fulfilled the characteristics required to be participants in this research. For example, all of them live in the city of Medan; aged between 40 and 59 years; have experienced practising suluk at Tarekat Naqsyabandiyah at least once; and they were easy to contact.

On the other hand, 200 participants were selected to represent non-saliks group as the control group. The same number of participants was selected to represent the non-saliks to balance the number of the salik group. These participants also fulfilled all the requirements to be participants in this study. For example, all of them live in Medan city; aged between 40 and 59 years; have not experienced practising suluk at Tarekat Naqsyabandiyah at least once; and they were easy to contact.

\section{B. Materials}

To collect data, this study used the psychological well-being questionnaire. The questionnaire of psychological well-being used in this research was adapted from Ryff's Scales of Psychological WellBeing (RPWB). [8] which measures six dimensions of psychological well-being, namely autonomy, environmental mastery, personal growth, positive relationship with others, goal in life, and selfacceptance.

\section{Procedure}

Research procedures were implemented in two stages, namely the preparation stage and the implementation stage. Finally, data analysis will be presented.

After summarizing the research questions, the research proceeded with the search for a theoretical framework to be used for discussing the research results. Meanwhile, the psychological well-being questionnaires was organized and prepared.

In the implementation stage of the research, the researcher determined the participants of the study and the data collection method. The participants of the research consisted of saliks who have practised suluk at the Tarekat Naqsyabandiyah and non-saliks. The researcher searched for data on the total Muslim population in Medan City, contacted the Muslim saliks and non-saliks in Medan City, introduced and persuaded them to participate in the study. The objectives and benefits of the study to the researcher and the participants were explained the study participants, including the details of the activities involved, and the time they would be required to be present for the process of data collection for the research. Then, the study participants were asked to fill the psychological well-being questionnaire.

During the closing session, the researcher thanked them for their cooperation in this research.

\section{RESULT}

The research results showed that the practice of suluk is significantly related to the psychological well-being among the saliks and non-saliks $(\beta=$ $.765 ; \mathrm{p}<.01)$ and all its aspects, that is, autonomy $(\beta$ $=.751 ; p<.01)$, control of environment $(\beta=.525 ; p$ 
$<.01)$, personal growth $(\beta=.520 ; \mathrm{p}<.01)$, positive relationship with others $(\beta=.598 ; p<.01)$, purpose in life $(\beta=744 ; p<.01)$, and self-acceptance $(\beta=.687$; $\mathrm{p}<.01)$.

In the mean scores of psychological well-being of salik (100.24), namely the autonomy (11.58), the environments mastering (17.31), personal growth (20.62), the positive relations with others (14.39), the purpose in life (26.77), and the acceptance of self (9.57)) were higher than the mean scores psychological well-being of non salik (67.24), namely the autonomy (6.66), environments mastering (12.64), personal growth (15.35), the positive relations with others (10.33), the purpose in life (16.24), and the acceptance of self (6.03).

\section{IV.DISCUSSION}

The research results showed that suluk practice has a significant positive relationship with the psychological well-being among the saliks and nonsaliks. The research results also indicated that salik's psychology well-being and its all dimensions (autonomy, environments mastering, personal growth, positive relations with others, purpose in life, and acceptance of self) are higher than the nonsalik's psychology well-being (autonomy, environments mastering, personal growth, positive relations with others, purpose in life, and acceptance of self).

The results of the reaserch in line with the opinion of Ryff \& Keyes [9], that the factors that affected psychological well-being are age, gender, culture, and life experiences. Therefore, thier life experience (practicing and not practicing suluk), their gender and culture will affect their psychological well-being (autonomy, environments mastering, personal growth, positive relations with others, purpose in life, and acceptance of self).

This finding is in line with studies which said that suluk is an effort, a serious attempt to cleanse the body and soul. It is done by repenting and emptying the personality from the corrupted characteristics (internal and external vice) and filling it with laudable and obedient characteristics, internal and external, namely (i) controlling and mastering the self, and handling of self-indulgence; (ii) cleansing the self from worldly influence. [10] The teachings of the tarekat provide the experience and the feeling of the self being deeply close to Allah and getting farther away from vice, increasing faith and adding piousness in performing religious obligations, and commitment and sincerity to help humanity. [11] People who orientate their life to spiritual and transcendental efforts report higher positive emotion, better personal condition, better physical health, paying more attention to others, and having higher positive well-being. [12]

James [13] said that the person who focuses on religious activities will feel what is called a religious experience. All of subjective religious experience is a source of deep religious emotion, associated with conscious-under conscious (conscioussubconscious) human. The religious experience is usually brief experiences that individuals feel that he has been in relation to something "bigger" than himself, namely God. During the events of this mystery, the individual feels more thorough and more complete and believe that hidden truths have been delivered to him, and he feels that something so important and meaningful have given him. Religious experiences and emotions that follow may be so positive, like enlightenment (illumination) spiritual depth, a feeling of relax and deep contemplation, taste Glory and secure when she entered the religious buildings, so it may help to regulate emotions that are less guarded toward spirituality. [14]

Religious and spiritual experience is a transcendental experience that is often so dramatic and left the impression the feeling that they have entered a state of higher consciousness (higher state of consciousness). The depth of religious experience often makes the individual's emotional nature. [15]

Furthermore, this research is in line with study which found that there is a positive relationship between people who pray and their subjective wellbeing. The relationship between ritual praying and deep devotion in meditative prayers, frequency of praying, and experience in praying are all correlated with subjective well-being. Those who perform prayers, feel the presence of Allah, and remember Him, recite their $d u a$ (prayers) accordingly, will feel deeply secure, and will feel a deep experience with Allah. They reported that they can feel a better subjective well-being. [16]

The study finding is in line with Wilbur's [17] theory which said that transpersonal or transego is 
higher than the personal level of ego in late adults. Hurlock [18] also mentioned that interest in religious matters occur more to middle aged men and women than when they are young. Ryff [19] mentioned that age is one of the factors that influence a person's psychological well-being. The dimension of goal in life declines when age increases. However, selfacceptance and relationship with others dimensions do not change when age increases.

However, the finding of the present study is not in line with the finding of the study by Ryff, [20] which said that life experience is one of the factors that influence a person's psychological well-being. Meanwhile, the finding of this study showed that practising suluk among the saliks and non-saliks is not the important factor that determine a person's psychological well-being. Apparently, other life experiences may well influence people's well-being. Ryff said that people's life experiences will differ and especially are determined by the place where they live, the nature of their work, and their respective specialized experience and depend upon the way they are interpreted.

This finding is in line with the finding of Aziz which said that the teachings of the tarekat develop individual piety and keep people away from vice, make them increase their faith and increase their piety when performing religious obligations and make them committed and sincere to help human kind. Maskhiyah said that the higher the intensity of the experience of the teachings of tarekat, the higher will be the obedience and seriousness of fulfilling the social aspects of religious teachings. The finding by Levin and Chatters also mentioned that religion has a significant and major influence on psychological health and well-being, especially the influence from religious organizations.

\section{REFERENCES}

[1] Nur, D. (2004). Tasawuf dan tarekat Naqsyabandiyyah pimpinan Prof. Dr. H. Saidi Syekh Kadirun Yahya. Medan: USU Press.

[2] Nur, D. (2004). Tasawuf dan tarekat Naqsyabandiyyah pimpinan Prof. Dr. H. Saidi Syekh Kadirun Yahya. Medan: USU Press.

[3] Ryff, C. D., \& Keyes, C. L. M. (1995). The structure of psychological well-being revisited. Journal of Personality and Social Psychology, 69, 719-727.

[4] Aziz, A. A. (2005). Kesalehan individu dan kesalehan sosial: Studi peran tarekat Qadiriah-Naqsyabandiyah di Lombok. Jurnal Penelitian Ke]islaman, 2(2), 188-210.

[5] Davidson, R.J., Kabat-Zinn, J., Schumacher, J., Rosenkranz, M., Muller D., Santorelli S.F., Sheridan, J. F. (2003). Alterations in brain and immune function produced by mindfulness meditation. Psychosomatic Medicine, 65(4), 564-70.
[6] Maltby, J., Lewis, C.A., dan Day, L. (2008). Prayer and subjective wellbeing: The application of a cognitive-behavioral framework. Mental Health Religion and Culture, 11(1), 119-129.

[7] Scully, D., Kremer, J., Meade, M.M., Graham, R., \& Dudgeon, K. (1998). Physical exercise and psychological well-being: a critical review. British Journal of Sport Medicine. 32, 111-120.

[8] Springer, K. W., \& Hauser, R. M. (2006). An assessment of the construct validity of Ryff's scales of psychological well-being: Method, mode, and measurement effects. Social Science Research, 35, 1080-1102.

[9] Ryff, C. D., \& Keyes, C. L. M. (1995). The Structure of Psychological Well-Being Revisited. Journal of Personality and Social Psychology, 69, 719-727.

[10] Al-Ghazali \& Hamid, A. (2004). Ihya’ lum al-din (Juz 4). Edit. Dr. Muhammad Tamir. Kairo: Muassasah Al Muhtar.

[11] Aziz, A. A. (2005). Kesalehan individu dan kesalehan sosial: Studi peran tarekat Qadiriah - Naqsyabandiyah di Lombok. Jurnal Penelitian Keislaman, 2 (2), 188-210.

[12] Leak, G. K., DeNeve, K. M., \& Greteman, A. J. (2007). The relationship between spirituality, assessed through self-transcendent goal strivings, and positive psychological attributes. In R. L. Piedmont (Ed.), Research in the social scientific study of religion, 18, 263-279).

[13] James, W. (1958). The varieties of religious experience: A study of human nature. New York NY: The Modern Library.

[14] Emmons, R. A. (2005). Emotion and religion. In R. F. Paloutzian, \& C. L. Park, C. L. (Peny.), Handbook of the psychology of religion and spirituality (hlm. 235-252). New York, NY: Guilford Press.

[15] Campton, W. C., \& Hoffman, E. (2013). Positive psychology: The science of happiness and flourishing. Belmont, CA: Wadsworth, Cengage Learning.

[16] Maltby, J., Lewis, C. A., \& Day, L. (1999). Religious orientation and psychological well-being: The role of the frequency of personal prayer. British Journal of Health Psychology, 4(4), 363-378.

[17] Wilbur, K. (1996). A brief history of everything. Boston, MA: Shambhala.

[18] Hurlock, E. (1996). Psikologi perkembangan, suatu kehidupan sepanjang rentang kehidupan (5th ed.). Jakarta: Penerbit Erlangga.

[19] Ryff, C. D., \& Keyes, C. L. M. (1995). The structure of psychological well-being revisited. Journal of Personality and Social Psychology, 69, 719-727.

[20] Ryff, C. D., \& Keyes, C. L. M. (1995). The structure of psychological well-being revisited. Journal of Personality and Social Psychology, 69, $719-727$. 